\title{
ADOPTION OF INNOVATIVE DRILLING TECHNOLOGIES IN UPSTREAM OIL AND GAS
}

\author{
Sylesh Nechully \\ Research Scholar, UPES, Dehradun, India \\ Dr. S.K. Pokhriyal \\ Professor and Head - Energy Management \\ School of Business - UPES, Dehradun, India
}

\begin{abstract}
This article describes in a nut shell, the changing attitude of Oil and Gas companies towards innovative drilling technologies in the down turn, some of the important innovations in drilling technologies and its relevance to upstream oil and gas, the pace of adoption of innovative drilling technologies in the upstream oil and gas and the need for an optimistic future outlook.
\end{abstract}

Keyword: Upstream, Drilling, Technologies, Innovation, Oil and Gas, Adoption

Cite this Article: Sylesh Nechully and Dr. S.K. Pokhriyal, Adoption of Innovative Drilling Technologies in Upstream Oil and Gas, Journal of Management, 6(2), 2019, pp. 1-18.

http://www.iaeme.com/jom/issues.asp?JType=JOM\&VType=6\&IType=2

\section{INTRODUCTION - CURRENT OIL AND GAS SCENARIO}

Oil and Gas industry has been in a down turn since 2014 - when the oil prices plummeted from $\$ 100$ per barrel in 2014 to $\$ 65$ per barrel in 2018. According to the Industry experts, the prices are not expected to rise beyond $\$ 70$ in 2019-2020. This down turn has adversely affected the revenues and profits of Oil and Gas companies. Till 2014, when the Oil and Gas companies where earning enormous profits, they never cared to do away with the inefficiencies in the system. The attitude was to "Drill more and Produce more". Now the situation has changed drastically. Oil and Gas companies have to focus on two fronts (1) Increasing Production (2) Reducing Capital and Operating Expenses (Ihsmarkit, 2015). Oil and Gas companies have to initiate innovation drives for cost cutting and efficiency improvements. Oil and Gas companies have to adopt innovative drilling technologies to meet the rising demand and to remain competitive (Tarver, 2018).

\section{SIGNIFICANCE OF INNOVATIVE DRILLING TECHNOLOGIES}

The days of "Easy Oil" are long gone. The demand for oil is expected to increase from 86 to 120 Million barrels per day in 2030. But the oil from conventional sources will increase only 
up to 85 Million barrels per day in 2030. Half of this gap is expected to be covered by bio fuels or natural gas. To meet the next half, the oil and gas industry will have to enhance the production from existing wells or revive the old wells or gain accesses to hydrocarbons in the hard to reach remote locations - Ultra deep drilling or Artic drilling. By 2030, the production of oil from reservoirs deeper than 600 Meters has to increase from 5 Million to 10 Million barrels per day (Tablot, 2010).

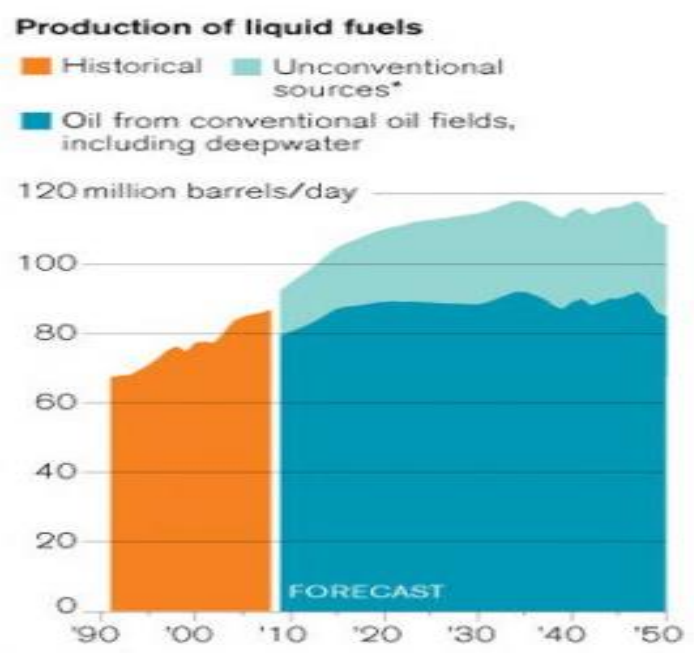

Figure 1 Future Oil Requirements (adapted from Tablot, 2010)

Innovative drilling Technologies help to reduce drilling costs drastically. Due to the deployment of innovative drilling technologies the drilling efficiency has increased to $150 \%$ in 2010 to 2015 period. The advancements in drilling technologies can facilitate a reduction of OPEX by $70 \%$ and CAPEX by 3 to $15 \%$. Innovations in upstream can enhance the Oil and Gas production from 2 to $8 \%$. A Formula to calculate the Well cost is given in the Figure 2. Innovative drilling technologies attack all these cost elements to bring the Well cost down (Ihsmarkit, 2015).

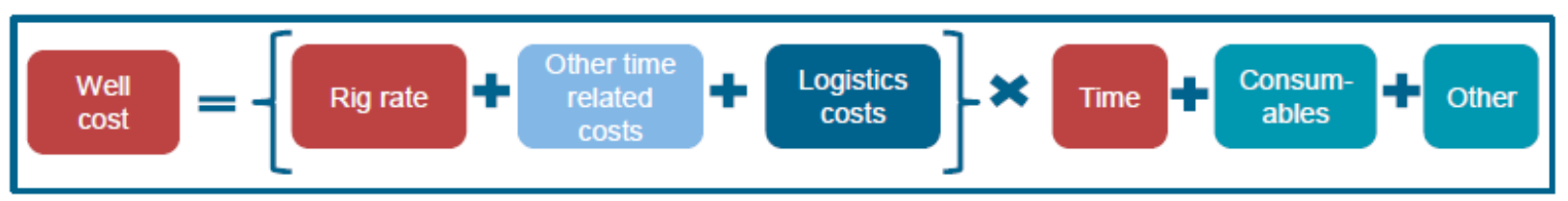

Figure 2 Well Cost Elements (adapted from OG21, 2014)

\section{STEPS INVOLVED IN THE DRILLING PROCESS}

Drilling a well is a very complex process involving 10 to 30 Service companies, each adhering to strict Safety and Environmental Standards. Drilling process starts with the planning phase. The Oil and Gas companies review the preliminary information collected about the prospective fields and decide to proceed further based on the Costs and Potential Reserve expectations, environmental impacts, Lease options and other risk factors. The scope of work is decided during the planning phase. The tentative location(s) for drilling is/are also decided. Data Evaluation Stage follows. The Data available - Mappings, Well logs or Existing Seismic data regarding the proposed field is analyzed to evaluate the Potential. Upon obtaining the favorable results, the next step is to Obtain Lease for the designated area. "The rights to drill" is secured by leasing the area from the owner /state. After Finalizing the Lease agreement, Oil and Gas companies have to apply for Drilling permit. To get this permit - Oil and Gas companies have to submit permit application, lease agreement, permit fees, water allocation, air emissions and 
proposed drilling program. The Tentative location(s) decided during planning stage is/are reconfirmed by 3D Seismic Surveys. 3D Seismic Survey helps to analyze the potential of the proposed fields. Once the potential is finalized, Drill Site location is selected. Before the actual drilling starts, Oil and Gas companies prepare a budgetary document called Authority For Expenditure (AFE) and this has to be approved. The Survey is considered as completed when the AFE is approved. Next step is the Drilling Site preparation. A Stick is placed at the exact drilling location. Access roads are created for getting access to the drilling location. Drilling Rig and Equipment are transported to the location and installed at the drilling location. Reserve Pit is dug to accommodate for the drilling fluids and mud discharges. These are either recycled or disposed in an environmental friendly manner. Arrangements for Accommodation, Water and Power are to be completed. Drilling process continues $24 \times 7$. Then the drill is installed at the designated location and equipment are mounted on it and connected to power sources and pressurized piping systems. Closed loop systems helps to do away with the reserve pits by recycling drilling fluids and muds. The next step is to drill the well bore. The drill bit is mounted on the drill pipe and as the drill bit makes its way through, mud is pumped in to the hole to cool the drill bit. The cuttings are flushed to the surface. Now the drilling pipe is removed and the surface casing is inserted to the well bore to keep it intact. It also serves to protect the fresh water sources from getting contaminated. The Casing is kept intact by pumping in the cement and filling the space between hole and casing. This also serves as a permanent barrier to protect the fresh water zones. Blow out preventer (On top of Well head) and Well head are connected to the Casing. Blow out preventers play an important role to contain the erratic down hole pressures (kicks) and uncontrolled flow of fluids. By any chance the well control is lost, BOP seals off the well bore. The cement that is pumped into the casing will be blocking the way for further drilling down to the reserves. A drill bit and pipe of smaller diameter is used to drill through the cement further down. Then again casing is inserted and held firm by pumping in cement to fill the gap. Again the drilling continues. The process is repeated till the desired depth is reached. Millions of dollars are invested in the drilling business. So at every stage of drilling, information are collected and analyzed to determine whether it is worth proceeding to the next stage. Drill Stem Testing (DST) is the commonly employed procedure to determine the commercial viability of a Reservoir. DST gives information regarding Formation properties, Reservoir Pressure, Fluid Samples and Flow rates. As the drilling progresses to further depths, the mud samples are collected and analyzed by the mud loggers. If the analysis yields favorable results, the drilling is stopped and the drilling pipe is removed from the bore. The DST tool is inserted through the well bore at the depth using a drill string where the favorable results were obtained - to study the properties of the formation. The DST tool is fitted with packers which expand and isolate the area where the study is to be conducted. The hydraulic valve on the DST tools opens up and the fluid enters the valve and through the drill string goes to the surface for evaluation. The fluid samples are taken several times a day and at times the process continues for days. When the well is drilled to the desired depth, the drill pipe is removed and a probe consisting of several logging tools (Neutron tool, Gamma Ray Tool, Sonic Tool and Resistivity Tool) which measures the rock and fluid properties within the formations is inserted. Geologist and Well logging crew monitors the process. As the probe is raised to the top, computers activate these tools and produce the graph called Well log which explains the properties of rock. Well logs give an idea about the rock structure and possible presence of deposits. Once commercial viability of a well is proven, another layer of production casing is inserted and gap between production casing and the hole - called annulus is cemented. The rig structure at the surface is no longer needed. It can be dismantled and transported from the site. A coil tubing unit is brought to the site to perforate the targeted zone. A Perforating gun is lowered to the desired depth and pressure is applied. This pressure sets off the charge in the perforating gun which makes holes though casing and cement to the targeted formation. The perforating gun is 
then brought out to the surface. Stimulation is required in most cases to establish production. Hydraulic Fracking is the commonly used method. Water, Sand and Small amount of chemicals are pumped at very high pressure using specialized equipment to the desired location to produce Cracks or Fractures. Oil flows from the reservoir to the well through these cracks/fractures. The sand pumped keeps the Cracks open facilitating the oil flow to the well. The process of stimulation is repeated across various locations in the well bore. Plugs are placed between each stage of Fracking to maintain the pressure. When the entire fracking process is completed, the plugs are removed to facilitate unobstructed flow of oil to the surface. The Frack fluid also flows back to the top along with the hydrocarbon. Frack fluids can be treated and reused for future fracking processes. This helps to reduce cost and save water. Frack fluids which cannot be reused are disposed. Subsequently the crew insert small diameter pipe called production tubing inside the production casing which serves as the conduit for the oil and gas to follow to the surface. It also acts an extra layer of protection to isolate the Fresh water zone from hydrocarbons. Next step is to install a "Permanent" well head. In most cases, at some point of the time or other, the natural down hole pressure will not be sufficient to pump out the hydrocarbons to the surface. Artificial lift will be provided by a pump jack to bring the hydrocarbons to the surface. The pumped out hydrocarbons are transferred to the heater treater which separates the oil from water and gas. The water is stored for further treatment or removed. The gas passes through the Mist extractors and is either stored or flared. The oil is taken to the storage tanks for further transport. An "Earthing Berm" is constructed around the production equipment as an environmental safety measure. During Field development in the leased area, additional wells are drilled to maximize the reserves recovery. Field development is a process done is several stages over a period of time. The aforementioned processes are repeated for other wells. An oil and Gas well can produce hydrocarbons for 25 to 30 years during Primary Recovery Phase. Over the years when the production declines, the life of the well is extended using Secondary and Tertiary Recovery methods. When the production from the well becomes commercially unviable - the final steps in the Well Life Cycle are Abandonment and Reclamation. Well head and associated equipment are removed. Well bore is filled in with cement, capped and marked by the company. Subsequently, the area is reclaimed and lease is relinquished back to the land owner (Oil Industry Training, 2017).

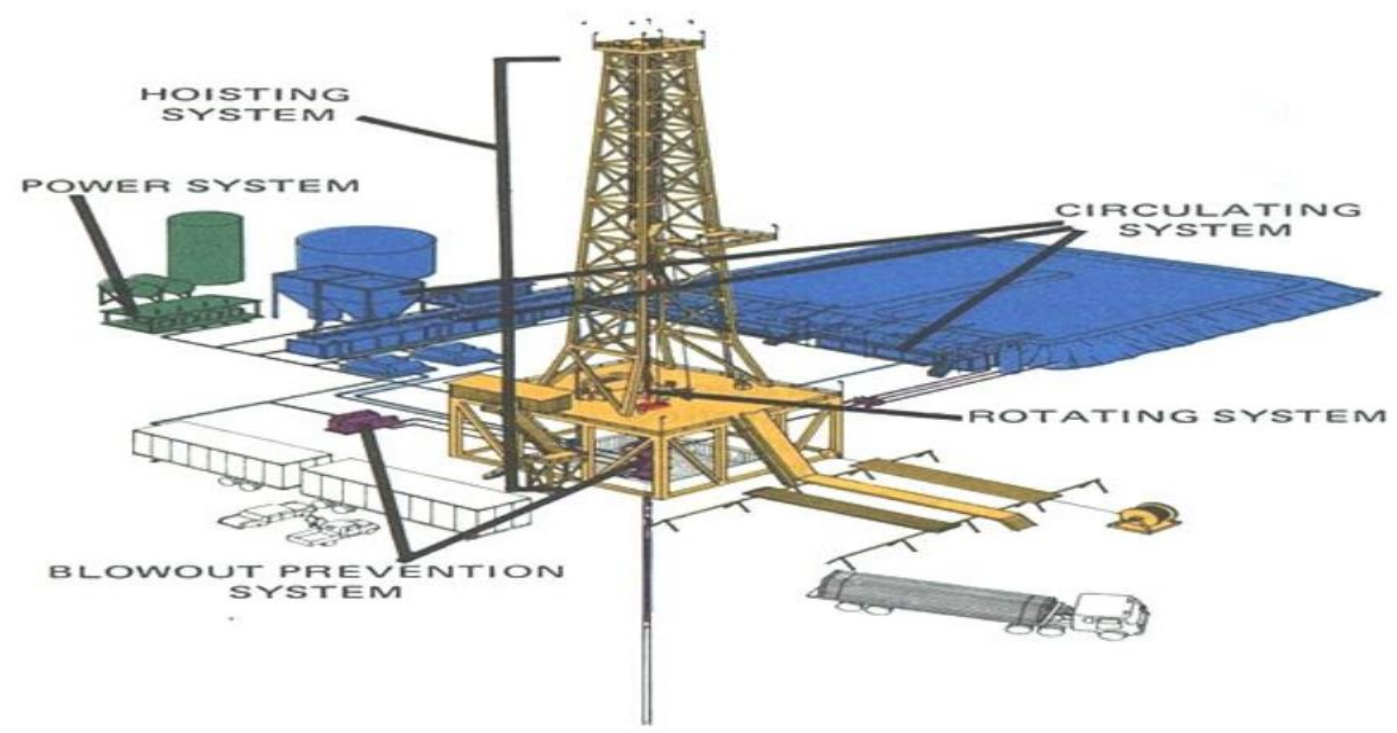

Figure 3 A Typical Rig (adapted from Oil Industry Training, 2017 


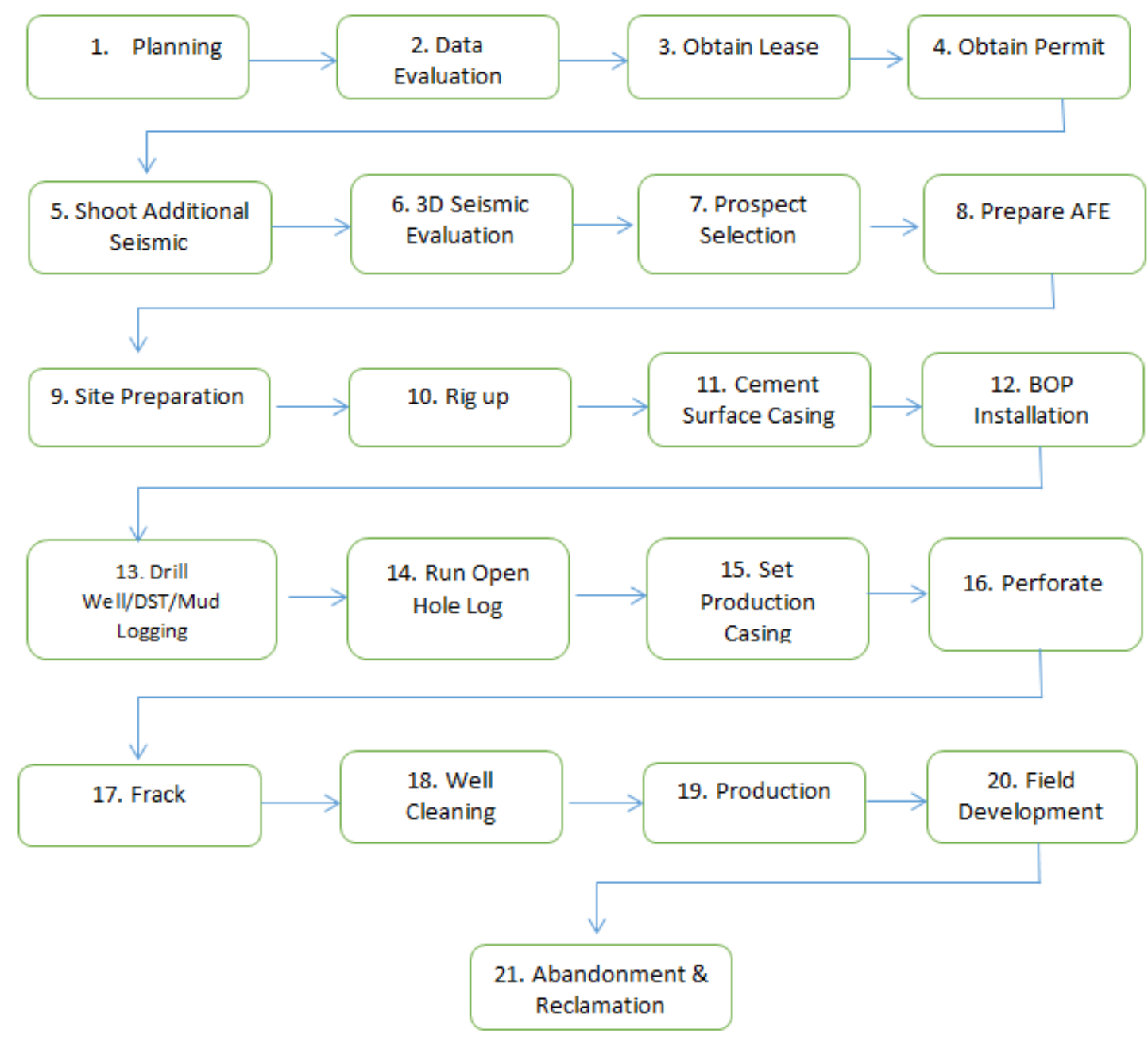

Figure 4 Steps involved in the Drilling Process (adapted from Oil Industry Training, 2017)

\section{A GENERAL DEFENITION FOR INNOVATIVE DRILLING TECHNOLOGIES}

Any new technology (ies) that can bring in product or process improvement(s) in any stage or stages of drilling process - Right from Planning, Production and finally all the way down to Plug and Abandonment stage - A General Definition that guides the researcher's further study.

\section{DRILLING TECHNOLOGIES: PAST, PRESENT AND FUTURE - A REVIEW}

\subsection{PAST AND PRESENT}

The Drilling technologies have come a long way from using Torpedoes for Fracking in 50s. Currently, water, sand and big powerful pump are being used for fracking. After the well is drilled down, horizontal drilling is done and water is pumped at very high pressure to create fractures in the rock. Subsequently sand is forced into these fractures to hold them open for the oil and gas to flow out (Badiali, 2014).

The commonly used drilling methods in the industry are (1) Cable tool drilling (2) Auger Drilling (3) Rotary drilling Techniques (4) Rotary air drilling (5) Down hole hammer drilling (6) Reverse circulation air drilling (7) Rotary mud drilling (8) Reverse circulation drilling mud. 
In Cable tool drilling, the drilling tool hanging from a wire rope is frequently lifted and dropped till the drill bit fractures the formation. Auger drilling is used in Soft rock and for Soil investigation. In Rotary drilling, the drill bit is attached to a hollow pipe and drill bit is rotated again the bottom of the hole to perform fracturing or digging action. Rotary air drill is used to drill in semi hard formations such as shale or sand stones. Down hole hammer drilling is the fastest method of penetrating hard rock. Rotary mud drilling uses drilling mud as the circulating medium. This is useful for drilling soft unconsolidated formations. Reverse circulating drilling - mud is used for drilling large diameter holes in soft formations (Direct Drill, 2015).

Rotary drilling is the most common and efficient technology used in oil and gas industry since its inception. The drill bits rotate continuously and drilling fluid is circulated through the bit and well bore to control the formation pressure, cool and lubricate the drill bit and remove the cuttings produced due to drilling. Directional drilling is the process of directing a well bore along a preplanned course towards the subsurface formation whose lateral distance and direction from the surface is known. The course of drilling can be modified based on the information given to drilling engineers. Horizontal drilling is the directional drilling in the horizontal direction. Horizontal drilling intersects a vertical well to stimulate it - to enhance the production. In the horizontal drilling, the drilling starts initially in the vertical direction and then progresses along a curved trajectory to reach the formations in the horizontal layer (Oil and Gas, 2017).

\begin{tabular}{|c|c|c|c|c|c|}
\hline $\begin{array}{l}\text { Type of } \\
\text { formation }\end{array}$ & $\begin{array}{l}\text { Cable } \\
\text { tool drill }\end{array}$ & Auger * & Rotary air & Rotary mud & $\begin{array}{l}\text { High-pressure } \\
\text { rotary air with } \\
\text { down-hole hammer }\end{array}$ \\
\hline Sand & Suitable & Fair & Not suitable & Suitable & Not suitable \\
\hline $\begin{array}{l}\text { Loose sand } \\
\text { and gravel }\end{array}$ & $\begin{array}{l}\text { Difficult - fair } \\
\text { (if casing driven) }\end{array}$ & Not suitable & $\begin{array}{l}\text { Difficult - not } \\
\text { suitable }\end{array}$ & $\begin{array}{l}\text { Suitable (with } \\
\text { fluid control) }\end{array}$ & $\begin{array}{l}\text { Not suitable } \\
\text { (see }{ }^{\star *} \text { below) }\end{array}$ \\
\hline $\begin{array}{l}\text { Loose coarse } \\
\text { gravels and } \\
\text { boulders }\end{array}$ & $\begin{array}{l}\text { Suitable } \\
\text { (if casing driven) }\end{array}$ & Not suitable & Not suitable & $\begin{array}{l}\text { Difficult - slow } \\
\text { sometimes } \\
\text { impossible }\end{array}$ & $\begin{array}{l}\text { Not suitable } \\
\text { (see }{ }^{\star} \text { below) }\end{array}$ \\
\hline Loam and silt & Suitable & Fair & Fair & Suitable & Not suitable \\
\hline Clays & Suitable & Fair & Suitable & Suitable & Fair \\
\hline $\begin{array}{l}\text { Puggy shale } \\
\text { and mudstone }\end{array}$ & Fair & Slow & Fair & Suitable & Slow \\
\hline Shale & Fair & Slow & Suitable & Suitable & Suitable \\
\hline Sandstone & Fair & Slow & Suitable & Suitable & Suitable \\
\hline Conglomerate & Slow & Not suitable & Suitable & Slow & Suitable \\
\hline $\begin{array}{l}\text { Limestone } \\
\text { and dolomite }\end{array}$ & Slow & Not suitable & Suitable & Fair & Suitable \\
\hline $\begin{array}{l}\text { Limestone with } \\
\text { small cracks or } \\
\text { fissures }\end{array}$ & Fair - slow & Not suitable & Suitable & Fair & Suitable \\
\hline $\begin{array}{l}\text { Cavernous } \\
\text { limestone }\end{array}$ & Slow & Not suitable & Suitable & Difficult & Suitable \\
\hline $\begin{array}{l}\text { Weathered } \\
\text { basalts }\end{array}$ & Slow & Difficult & Suitable & Suitable & Suitable \\
\hline $\begin{array}{l}\text { Thick layered } \\
\text { basalts }\end{array}$ & Not suitable & Not suitable & Slow & Slow & Suitable \\
\hline
\end{tabular}

Figure 5 Commonly Used Drilling Methods (adapted from Direct Drill, 2015)

There are times when Oil and Gas reserves are located in various layers underground and in such scenarios, Multilateral drilling is employed. Multilateral drilling allows companies to do away with multiple wells on the surface. From one well it is possible to dig other wells for 
access to reserves in various layers at different depths. Multilateral drilling facilitates better reservoir management and enhanced recovery. It also reduces overall drilling and completion costs (Quora, 2018).

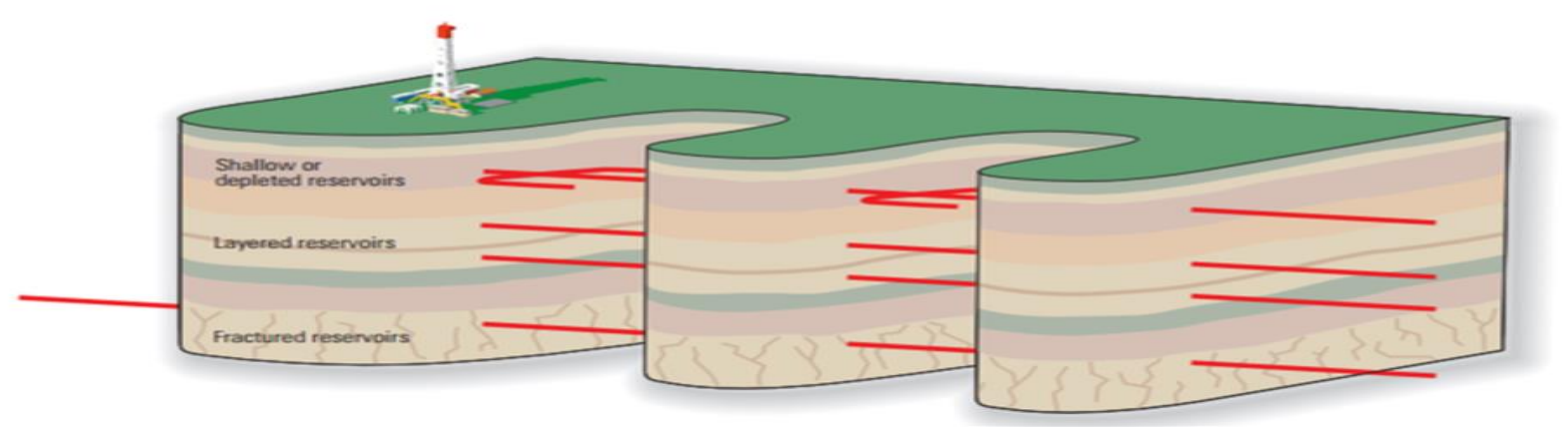

Figure 6 Multilateral Drilling (adapted from Quora, 2018).

\subsection{FUTURE}

Extended reach drilling allows access to reserves which are far off from the drilling rig. This also helps to access reserves where vertical drilling is not possible - in environmentally sensitive areas. This technique substantially reduces the need for pipe lines and other subsea equipment. Extended reach drilling also allows the access to offshore reserves near to onshore from onshore itself (Quora, 2018).

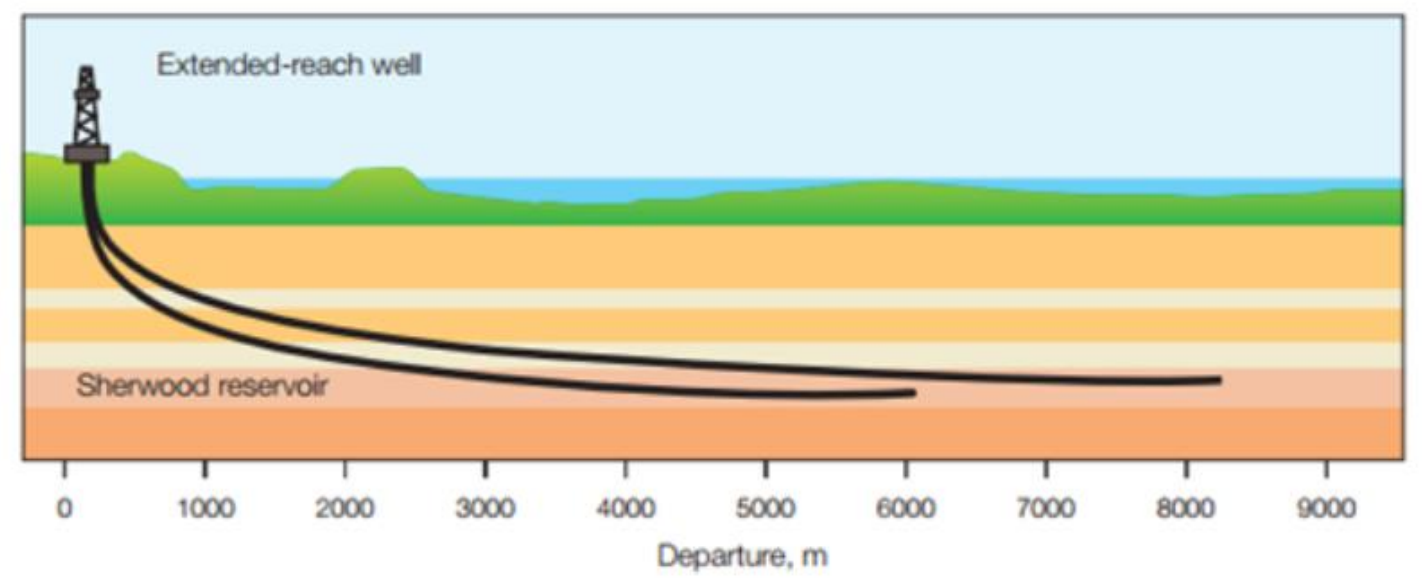

Figure 7 Extended Reach Drilling (adapted from Quora, 2018)

Ultra-Deep Drilling Technology is used if the drilling is required in the range of $5-10$ Kms. The drilling cost grows exponentially for every Kilometer after 4 Kilometers. The deployment of existing technologies for drilling beyond $4 \mathrm{Kms}$ will be very expensive (Geothermal, 2009). The two approaches used in Ultra Deep Drilling for extreme temperature (300 to 400C) and pressure conditions (Upto 1000 bar) are Waterjet and Electrical Discharge Technologies.

Water Jet rock cutting reduces the forces required by the drill bits to cut the rocks. It also reduces wear and tear, machine vibrations and dust produced (911 Metallurgist, 2018). 


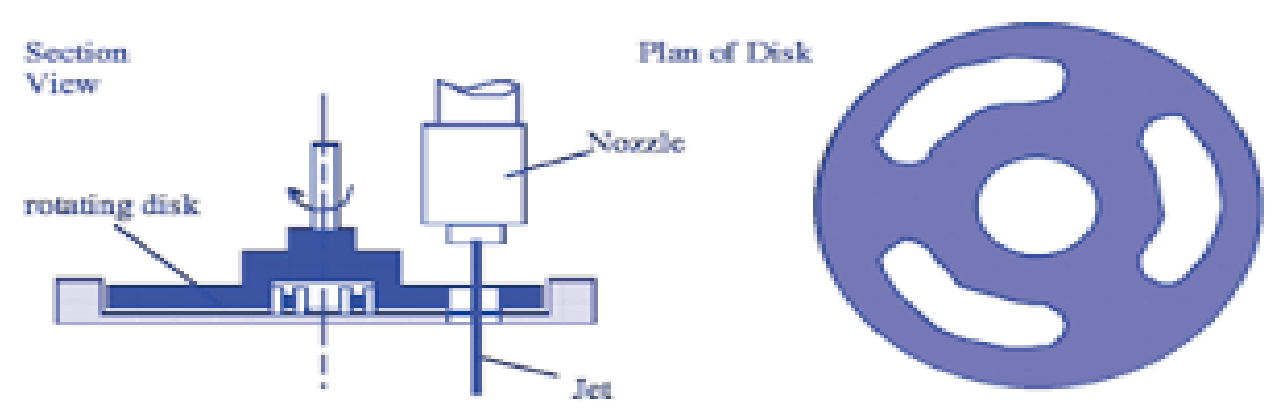

Figure 8 Water Jet Rock Cutting (adapted from 911 Metallurgist, 2018).

Plasma deep drilling uses rotating plasma arc at temperatures of around 6000C to drill through the rock. The advantages of this innovation are that it has systems in place to control overall tool operations. Plasma drilling uses a contactless tool. Drilling bits have no moving parts to cause wear and tear. It is Cost effective, and has Higher drilling rates and Lower energy consumption compared to conventional methods of drilling. Chemical Plasma drilling is the process of using nitric acid as the oxidizing agent to crush the rock by high speed combustion (Wikipedia, 2018).

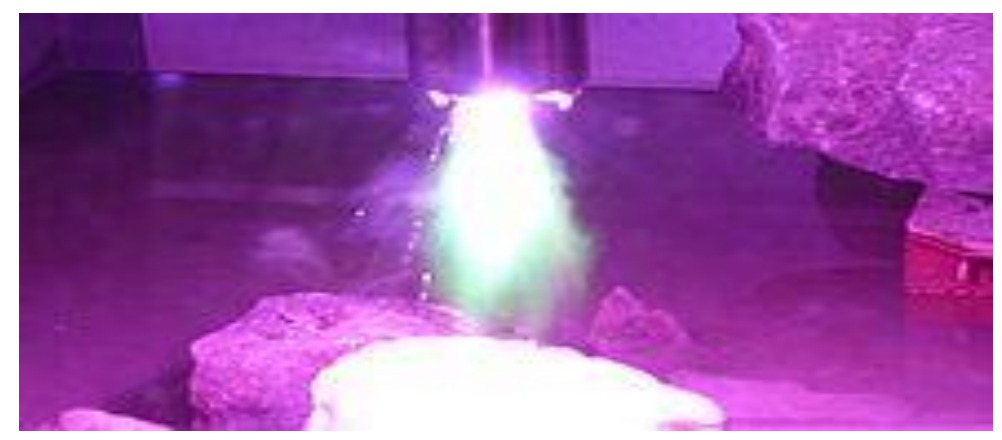

Figure 9 Plasma Deep Drilling (adapted from Wikipedia, 2018)

Hydro Thermal Spallation Rock drilling uses large down hole burner to apply heat shock for breaking rocks. The process uses focused jet of superheated water on rock surface creating thermal stresses which in turn results in breaking of rocks in to small disk like fragments. The main advantages of Hydro Thermal Spallation drilling are reduced cost, reduced replacement of drill bits, less trip time and Contact less drilling (Wikipedia, 2018).
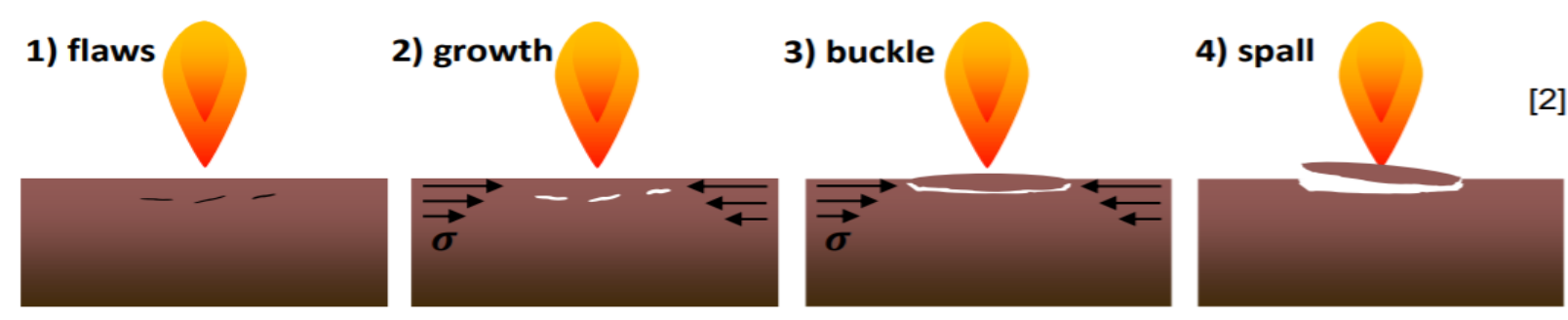

Figure 10 Hydro Thermal Spallation (adapted from Wikipedia, 2018)

Laser Drilling is the process of focusing laser beam on the area where the drilling is required. The concentrated beam of laser provides sufficient heat to increase the temperatures beyond the melting point of the rocks. The energy required to remove a piece of rock remain the same once the temperature exceed the threshold levels. The process is many times faster than the conventional methods. Laser drilling rigs requires less space compared to the conventional ones. Cost of drilling is also reduced almost 10 times (SPIE, 2014). 


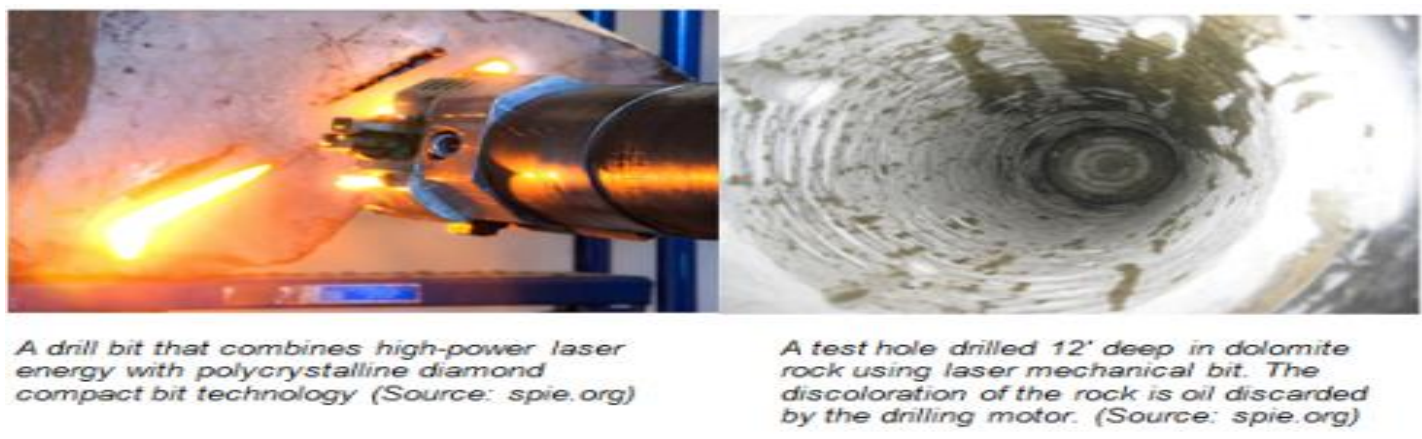

Figure 11 Laser Drilling (adapted from SPIE, 2014)

Turbine drilling solutions have faster penetration rates in hard rock formations. Turbine drilling solutions provide better reliability, steerability, better downhole life, reduced tripping and down time, increased efficiency and reduced cost per meter of drilling. Turbine drilling solutions with Anti Sticking Device Technology prevents bit sticking and stalling in harsh conditions (Oil and Gas Product News, 2015).

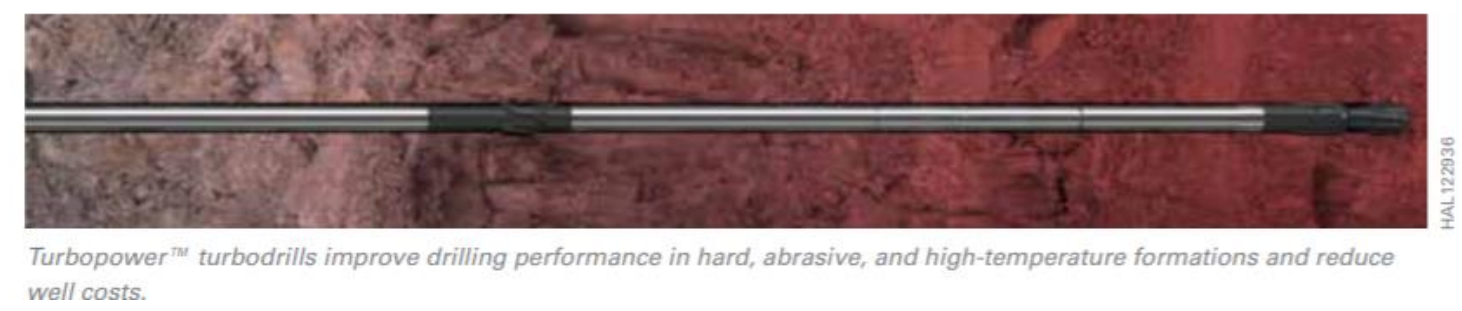

Figure 12 Turbine Drilling Solutions (adapted from Oil and Gas Product News, 2015)

Automated drilling is another innovation worth mentioning. With the conventional technologies, the cost involved in exploiting resources like shale gas and coal bed methane is exorbitant. Automated drilling substantially reduces the number of wells and work force and there by enhances speed, efficiency and safety. The sensors installed on the drill bits monitor the trajectory of the drill bit. The whole drilling system is monitored and controlled by a SCADA system where all the relevant parameters are logged. Smart drilling is the combination of world class technologies and expertise to manage oil and gas well. It's a marriage of Technology and Thinking. Smart oil filed technologies monitor all assets - local and remote and log and control the critical parameters from a central location in real time. Smart oil fields provide video stream to a central location facilitating better decision making in minimum time. The managers can get connected to the critical assets $24 \times 7$ (IEA Geothermal, 2016).

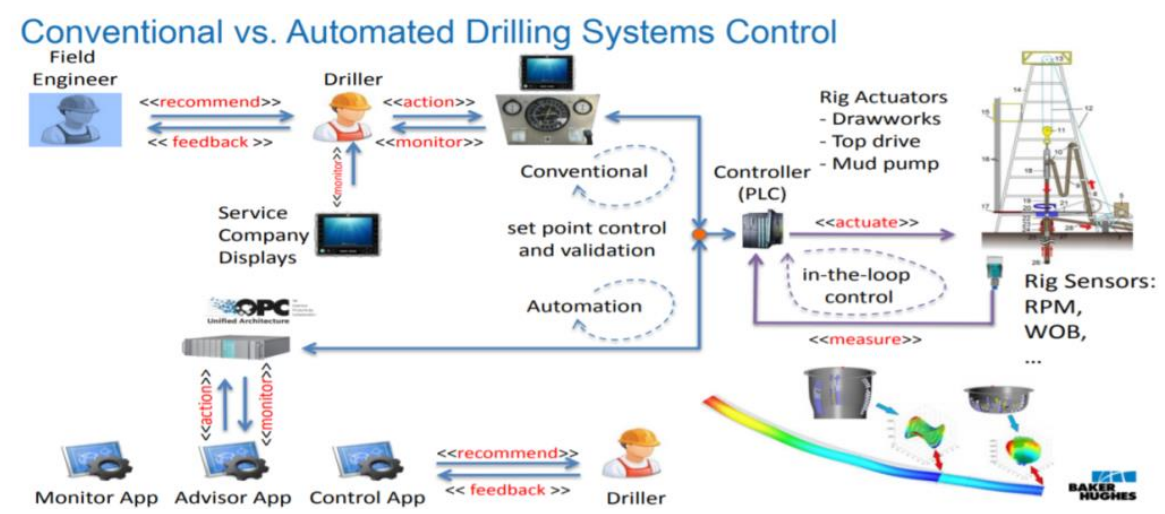

Figure 13 Conventional Vs Automated Drilling (adapted from IEA Geothermal, 2016) 
Dynamic under balanced drilling (DUBD) combines the advantages of Over balanced drilling and Underbalanced drilling and eliminates its disadvantages. In DUBD, the pressure drop is created below and around the drill bit and above the bit it is normal. So below and around the bit, it is under balanced and above the bit it is over balanced. DUBD provides higher ROP, saves time and cost, and gathers data while drilling (Shirkavand, Hareland and Olson, 2010).

Seabed Rig As has developed a "New Autonomous Drilling Rig" which can be used for Artic and Ultra Deep Water environments. Drilling from the ocean surface for these environments is very costly - $\$ 600,000$ per day and the operations can be stopped any time due to bad weather. The new rig sits on the ocean floor and will be powered up and operated from a ship on the Ocean surface. Robots will be mobilized on the Rig. This innovation makes it possible to tap $40 \%$ of the reserves located in the extreme areas. The technology is environment friendly with no discharge to the ocean (Energid Technologies, 2018).

Mono-diameter well technology from Shell facilitates the tapping of very remotely located oil and gas deposits. In Conventional drilling process, as the drilling goes deeper and deeper, the diameter of the well bore get reduced and companies have to ensure that the bore hole is sufficient wide enough for commercial production. A mono diameter well is a single constant diameter well throughout the depth which facilitates the accessing of reserves which are not currently accessible with the available technologies. When a particular section of a hole is drilled, a specially made liner is inserted to that section. The liner is expanded mechanically when inserted. The next section of the drilling starts and the liner is inserted to secure the section. The process is repeated till the desired depth is reached. A mono diameter well requires only less rock to be drilled and is environmental friendly (Shell, 2018).

Electro Impulse Technology can be employed for drilling through hard rocks - Which is extremely difficult using the conventional technologies. Two Electrodes are placed at the desired location of drilling and high voltage electric impulses are applied to pulverize the hard rocks. The voltage transients create stresses greater than the strength of the rock to pulverize it. The voltage transients applied are within the range of $300-600 \mathrm{kV}$ with a rise time less than 150 ns (IEA Geothermal, 2016).
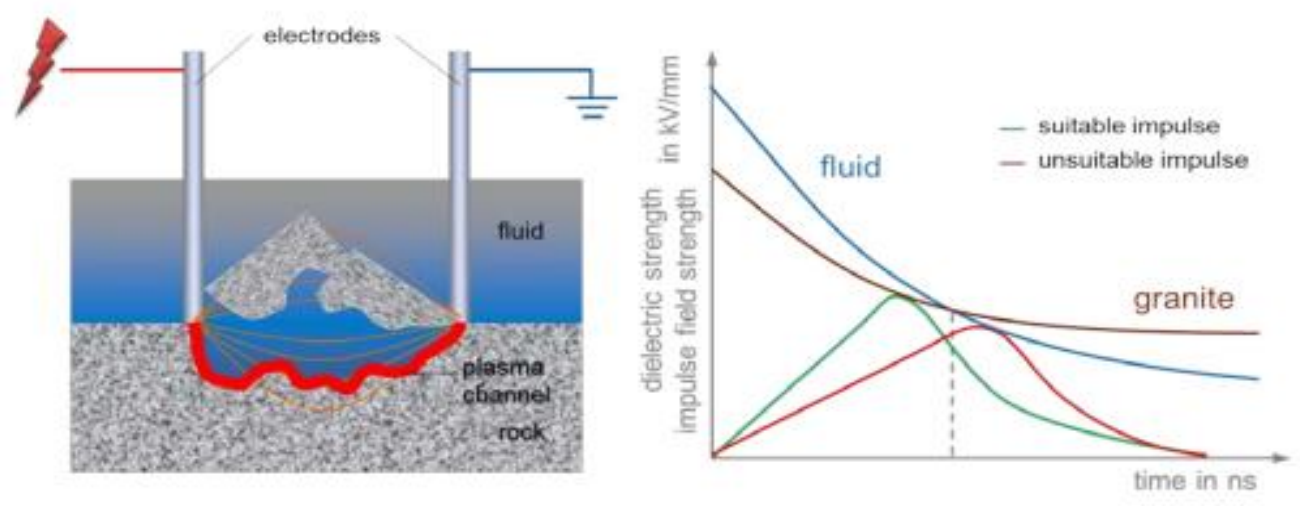

Figure 14 Electro Impulse Technology (adapted from IEA Geothermal, 2016).

SkyStrat Driling Rig is an innovation from Cenovus - A Flying Rig. The drilling rig can be transported to remote location using helicopters - one piece of the rig at a time and the transported parts are assembled at the location. The flying rigs are used to drill test wells - to determine whether an area is worth pursuing for hydrocarbons. The equipment from mining industry were adapted to build a rig - smaller in size and lighter in weight. No access roads are to be built (Cenovus, 2018). 
GeoForm is a sand management solution innovated by Baker Hughes which uses advanced polymer technology to operate in complex well profiles. The technology helps production from reservoirs up to depth of 3,000 Ft - while preventing sand migration to the bore. The technology helps to do away with several engineers, specialists and other complex equipment - the typical gravel pack operations (Boman, 2018).

Halliburton HCS Advantage One is a Cementing System which facilitates complex cementing in offshore deep and ultra-deep water. It can be used for normal cementing operations as well. This innovation facilitates remote cementing and predictive maintenance operations (Presley, 2017).

The innovation introduced by Texas University in the area of Fracking is Zipper Fracking. Zipper fracking allows drilling of two wells side by side and fracking them simultaneously. Fractures created form a Zipper pattern and allows both wells to produce more oil and gas (Kamaludhin, 2014).

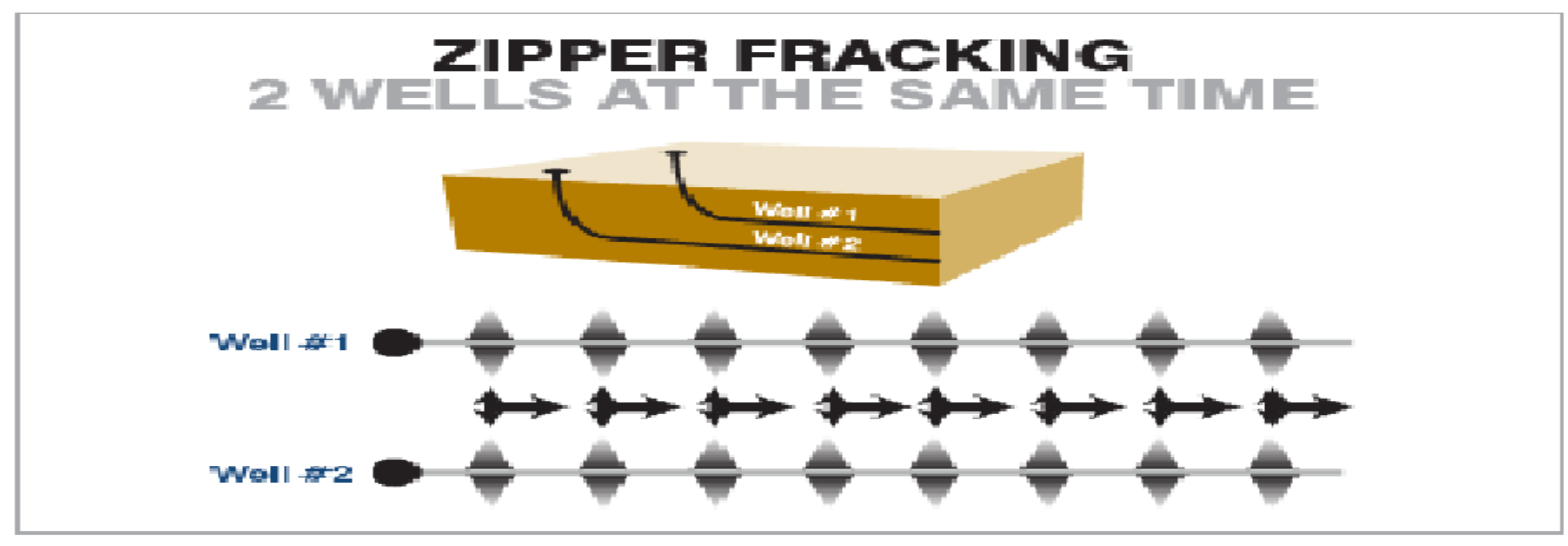

Figure 15 Zipper Fracking (adapted from Kamaludhin, 2014)

LPG Fracking or Gas Fracking is seen as an alternative to Hydraulic Fracking. Instead of water, a thick propane gel is used for Gas Fracking. Propane Gel is pumped in to the well to create high pressure and this pressure cracks the rocks and subsequently oil/gas comes to the surface. The Propane gel contains "Proppants - Sand/Man made material" to hold the cracks open. The advantage of using this technology is that unwanted materials like sea bed salts, Chemicals etc are not brought to the surface. The Propane Gel that comes out can be reused (Milmo, 2011).

Some of the innovative EOR methods followed by Oil and Gas companies are (1) Thermal Intervention (2) Chemical EOR (3) Microbial EOR. Thermal intervention is the process of injecting steam in to the wells to extract heavy petroleum like heavy oils/oil sands. The disadvantage of this method is that the energy requirement to generate the steam makes the method prohibitive to implement. Chemical EOR is the process of injecting polymers and alkaline compounds to loosen the oil to push it to the surface. This method is $20 \%$ more efficient than the conventional EOR. Only disadvantage is that the method is not suited for wells with high temperature and Salt and Sulphur content. In Microbial EOR, Microorganisms are used to generate methane from heavy oils and this is pumped back to the well to push light oil from the wells. Microbial EOR has been in vogue since 1950 but commercial application of this started recently. A study conducted in Malaysia enhanced the production by $47 \%$ within 5 months' time but still the oil and gas professional are showing reluctance to use these methods in the fields (Nielsen, 2010).

Ultrasonic Technologies are used to enhance the oil recovery for failing wells. An Ultrasonic source is inserted deep into the failing well and this technology enhances the flow 
of oil through the rock and decreases the viscosity of the oil making it easier to pump. These technologies are suited for Wells with high porosity and Permeability. Ultrasonic Technology enhances the oil recovery by $30-50 \%$ in failing wells (Abramova, et al., 2014).

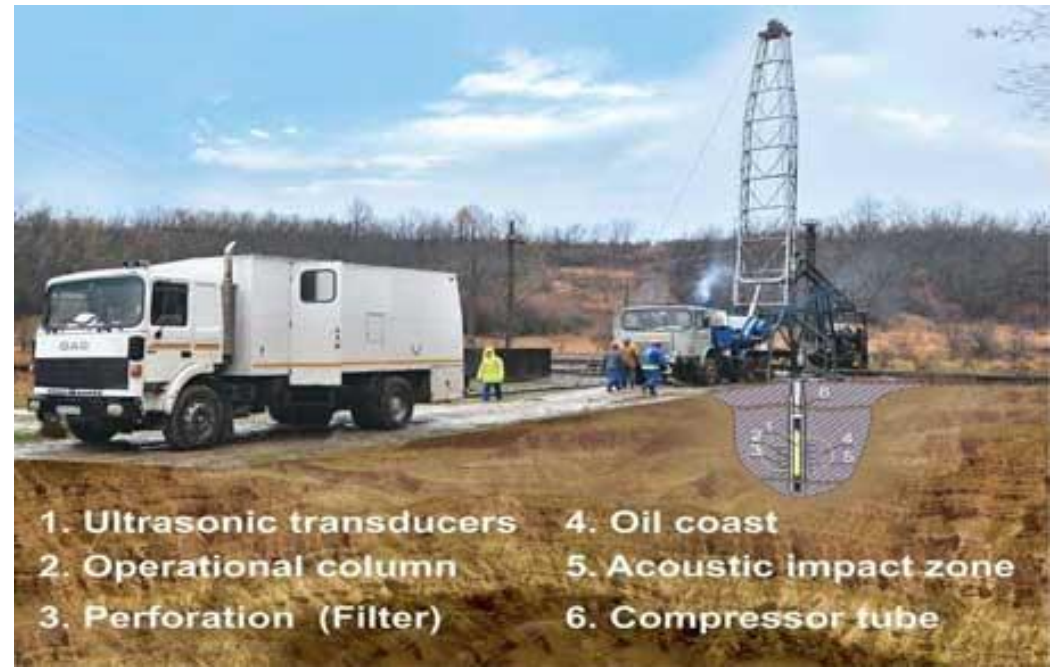

Figure 16 Ultrasonic Oil Recovery (adapted from Abramova, et al., 2014)

Micro wave oil recovery is considered as the next big thing by Oil ang Gas pundits. High power gigahertz emitter is used to create, stabilize and steer the micro wave beam to the formations. Water found in the deposits is converted to steam and it pushes the oil upward to the well bore. Once the initial oil and water is removed, the well becomes more transparent and microwave beams can go farther up to 80 feet from the well bore. This technology can also be used to remove the impurities blocking the oil flow in the existing wells. Micro waves can melt paraffin and convert water to steam (Wang, 2016).

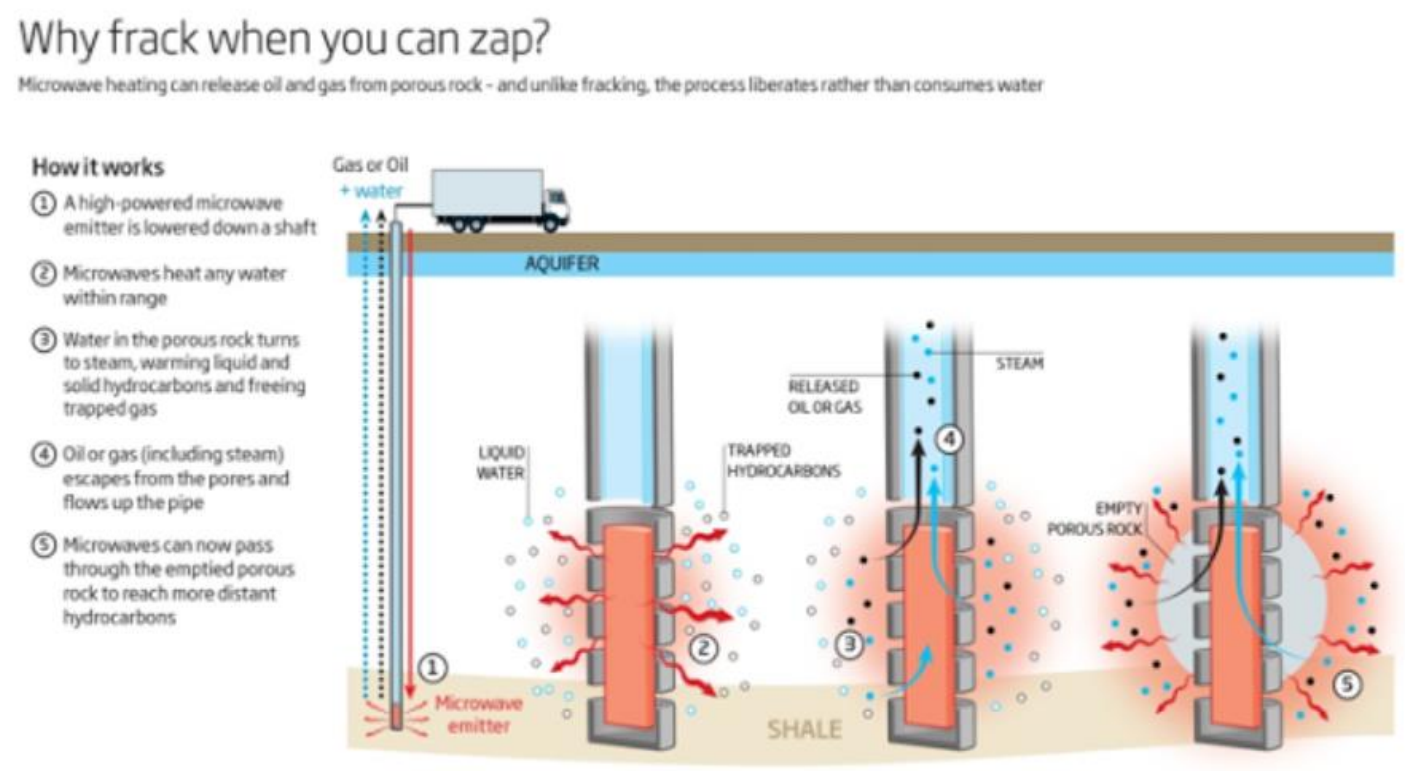

Figure 17 Microwave Oil Recovery (adapted from Wang, 2016)

Smart water flooding is another alternative for EOR. In Smart water flooding, water with appropriate composition of salinity and ionic content is injected. Ionic Composition/Salinity enhances the oil recovery up to $10 \%$. The advantages of Smart water flooding are (1) Lower 
cost due to usage of existing infrastructure (2) Greater ROI (3) Improved monitoring and surveillance of the project (Zahid, 2012)

Solar powered Oil Recovery is another technology worth mentioning where solar energy is used to produce low cost steam. This stem is injected to heavy oil filed to heat the heavy oil and to enhance the production. The sunlight is concentrated on the field water using mirrors and the water is converted to high pressure steam (Nahkle, 2018).

Floating nuclear power plants can supply power to offshore oil and Gas. These floating nuclear power plants can be either self-propelled or they can float on ice breakers. Russia is the first country to experiment with the Floating Nuclear power plant - called Akademik Lomonosov. These floating nuclear power plants do not have to be refueled for an extended period of time and can provide a constant power. Once the project is finished, it can be moved to other locations. The costs are expected to be lower than that of diesel power generators (Becker, 2018).

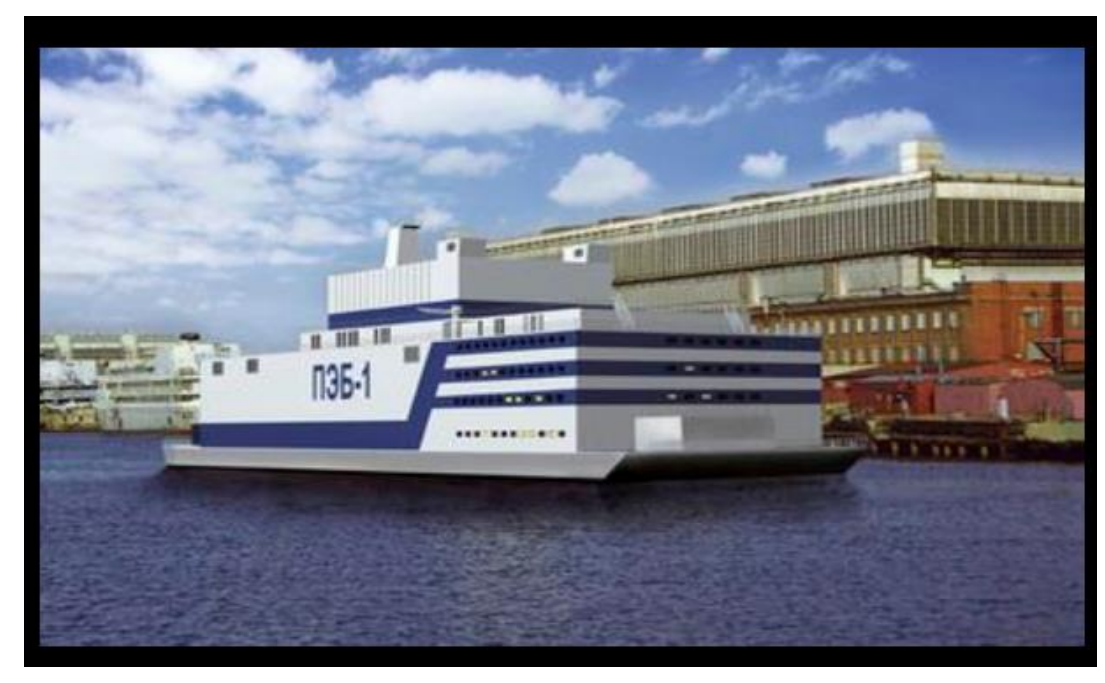

Figure 18 Floating Nuclear Plant (adapted from Becker, 2018)

Floating Processing Plant helps to liquefy the output from small offshore gas fields. Currently Malaysian Oil Company - PETRONAS operates a Floating Process Plant near to Sarawak (Nahkle, 2018).

Block chain Technology is a distributed ledger technology which enhances efficiency by modifying the workflows. Different tools and equipment from same or various vendors can be connected to a Block chain as different nodes. Main contractor and Sub contractor can couple algorithms and data as different blocks in the form of transactions. Whenever a change is made in one block it gets reflected in other blocks as well. The changes made can be verified and can be updated from anywhere any time globally. This technology facilitates various down-hole tools and other equipment in the block chain to interact and transact between them. Block chain facilitates the self-monitoring and correction of equipment/tools connected to it (Blockgeeks, 2018).

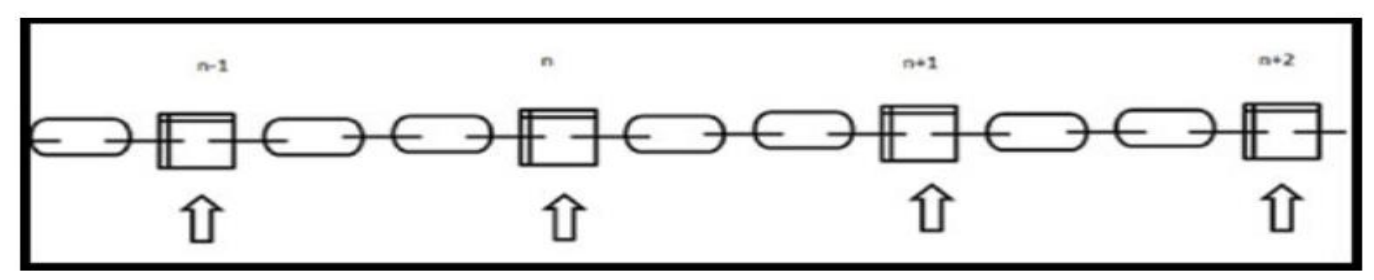

Figure 19 Black Chain Technology (adapted from Blockgeeks, 2018). 
IoT helps upstream to make decisions based on the collected data. IoT collects, cleans and models data for relevant information. IoT also enables companies to perform predictive maintenance. IoT helps companies to retain valuable information as one generation of executive leaves and the next generation assumes responsibilities (Boman, 2017).

The Hydrocarbon Early and Automatic Detection System detect the smallest of hydrocarbon leaks in the shortest time with highest precision and reliability there by enhancing the safety of personnel. This capability is achieved using advanced radars, infrared sensors and analytics. It is capable of proving $24 \times 7$ unmanned leak detection with alarm function for any abnormal leaks (Nahkle, 2018).

OG21 (2014) reports the Six areas where innovative technologies can make a difference (1) Managed Pressure Drilling on Floaters (2) Expandable Tubular Technology (3) High Speed well communication (4) Steerable drilling liner (5) Automation and autonomous systems (6) Plug and abandonment. Managed Pressure Drilling helps to control the annular pressure profile throughout the bore. Hydraulic pressure is adjusted according to the down-hole pressure limit. Expandable Tubular Technology provides capability to isolate the selected zones from down hole problems. This technology provides opportunities for slimming down well designs. Corroded tubular can be repaired by providing cladding over the damaged pipes. High speed well communication provides high speed communications from and along the well. This is achieved by placing sensors along the drill string. As the drill string moves, data are collected and simultaneously transmitted. Steerable drilling liner provides the capability to drill and line the well simultaneously. Automated/Autonomous drill floor operations standardize the operations using robots enabling time savings in pipe handling, tripping etc. It enhances operational reliability. Operations become independent of Rig Crew or Shift. Innovative Plug and abandonment technologies like "Perforate, Wash and Cement Tool" perforates the casing, washes the space behind the casing followed by releasing the upper and lower cup and finally plugs by pumping the cement to the space between upper and lower cups (OG21, 2014).

\begin{tabular}{|c|c|c|}
\hline S No & Areas for Innovative Technologies & Scope for Improvements \\
\hline 1 & Managed Pressure Drilling & $\begin{array}{l}\text { Increased Revenue by Accelerated Drilling, Reduced Safety and } \\
\text { Environmental Risk, Increase Revenue by drilling wells } \\
\text { problematic to drill, Cost reduction through reduction in NPT and } \\
\text { Casing material. }\end{array}$ \\
\hline 2 & Expandable Tubular Technology & $\begin{array}{l}\text { Less NPT, Fewer Casing and Reduced Foot Print, Drilling well } \\
\text { under depleted reservoir conditions, Improved reputation due to } \\
\text { reduced foot print. }\end{array}$ \\
\hline 3 & High Speed Well Connection & $\begin{array}{l}\text { Improved well integrity and safety by early detection of kicks and } \\
\text { losses, Reduced NPT by detecting problems early, Less need for } \\
\text { circulating the well and reduction of drill string connection time. }\end{array}$ \\
\hline 4 & Steerable Drilling Liner & $\begin{array}{l}\text { Increased Robustness - Less risk for side tracks, Reduced time - } \\
\text { Tripping of liner and need for hole conditioning. }\end{array}$ \\
\hline 5 & $\begin{array}{l}\text { Automated/Autonomous Drill Floor } \\
\text { Operation }\end{array}$ & $\begin{array}{l}\text { Cost efficient drilling operations, High Operational reliability and } \\
\text { HSE Improvements }\end{array}$ \\
\hline 6 & Plug and Abandonment & $\begin{array}{c}\text { Avoid large cost to business and society, Free up organizational } \\
\text { resources to value adding activities, Free up rigs and services for } \\
\text { value adding activities. }\end{array}$ \\
\hline
\end{tabular}

Figure 20 Broad Areas for Application of Innovative Technologies Vs Benefits (adapted from OG21, 2014) 


\section{ADOPTION OF INNOVATIVE DRILLING TECHNOLOGIES IN UPSTREAM OIL AND GAS}

There are many innovative drilling technologies available in the market for Oil and Gas companies to adopt - to enhance production and reduce cost. But Oil and Gas is notoriously slow to adopt innovative drilling technologies. Many of the "so called" innovative drilling technologies have been in market for decades. But Oil and Gas lacked the "Attitude" or "Drive" to experiment with the Drilling Innovations (Aviles, 2015; Greenberg, 2012).

\section{IMPACT OF SLOW/NON ADOPTION OF INNOVATIVE DRILLING TECHNOLOGIES}

The Impact of Slow or Non adoption of Innovative Drilling Technologies will be the missed or delayed opportunities to enhance production and reduce cost - In short, the opportunities to enhance the efficiency of Oil and Gas companies will be totally missed or delayed indefinitely (Oil and Gas Journal, 2014; Medal, 2017).

\section{FUTURE OUTLOOK}

There has to be a paradigm shift in the "Mind Set/Attitude" of Upstream Oil and Gas - From "If it is not broken, then why fix it" to "Let's change the obsolete (giving satisfactory results) with an innovation (capable of giving better results) available in the market". Open innovation is the panacea for all innovations adoption related problems in upstream drilling. Open innovation is the process of capitalizing on the inflows and outflows of information to accelerate innovation adoption and to use these innovations to outperform the competition. Open innovation in drilling happens when operators, service companies and contractors join hands to promote process and product innovations. In the Upstream Drilling, Open innovation can be explored in two ways. (1) Outside in - To bring in fresh ideas/new technologies from other industries. (2) Inside out - To explore the underutilized opportunities within the organization or to generate innovative ideas from within and disseminate the ideas to the partners in the network. Open Innovation in drilling has the potential to disrupt the operations in upstream.

\section{CONCLUSION}

Open Innovation has the potential to alter the economics of the upstream. Key Processes, Open innovation can influence in the future are (1) Logging Tools (2) Real Time Down Hole Streaming (3) Closed Loop Automation (4) Managed Pressure Drilling (5) Automated Casing Running and Cementing of the Wall (6) Radio Frequency ID Down Hole Tools (7)Survey Management (Nunoo, 2017).

Even though, Open Innovation in the Upstream is a "Promising Concept", there are many challenges/barriers for implementation. Not many studies are done regarding the Barriers or Challenges to Open Innovation in Upstream Drilling Technologies. These studies have to be Region/Country specific as many barriers/challenges are regions/country specific. So there exists scope for region or country specific studies to unravel the challenges or barriers to implementation of open innovation in upstream drilling technologies. 


\section{REFERENCES}

[1] Abramova, A., Abramova, V., Bayazitov, V., Gerasin, A. and Pashin, D., Ultrasonic Technology for Enhanced Oil Recovery. Engineering, 6, 2014, pp. 177-184

[2] Aviles, M, Technology Innovation and Adoption in Oil and Gas. Why did it slow down?[online] Available at: <https:// www .forbes .com/ sites/ drilling info /2015 /07 /14 /technology-innovation-and-adoption-in-oil-gas-industry-why-did-itslow/\#55a3e7013d1c>[Accessed 29 November 2018], 2015

[3] Badiali, M, New Drilling Technologies that Will Shatter US Oil Expectations. [online] Available at: <https://dailyreckoning.com/2-new-drilling-techniques-that-will-shatter-usoil-expectations/ > [Accessed 30 November 2018], 2014

[4] Becker, R, This nuclear power plant has been called a 'floating Chernobyl,' but is that just hype? [online] Available at: <https:// www. theverge. com/2018/5/2/17313174/ floatingnuclear-power-plant-russia-academik-lomonosov-chernobyl-titanic > [Accessed February 21, 2019], 2018

[5] Blockgeeks, What is block chain technology? [online] Available at: <https://blockgeeks.com/guides/what-is-blockchain-technology/> [Accessed 29 October 2018], 2018

[6] Boman, K, Putting the IoT in Drilling. [online] Available at: < https://www.oedigital.com/news/445441-putting-the-iot-in-drilling $>$ [Accessed 05 February 2019], 2017

[7] Boman, K., Simplicity Leads Subsea Technology Innovation. [online] Available at: <http://www.drillingcontractor.org/simplicity-leads-subsea-technology-innovations49008> [Accessed 09 September 2018], 2018

[8] Geothermal, Ultra-Deep Drilling Technologies for Geothermal Energy Production. [online]Availableat:<http://www.geothermalenergy.org/pdf/IGAstandard/ISS/2009Slovak ia/VIII.5.Kocis.pdf> [Accessed 12 January 2019], 2009

[9] Greenberg, J, Technology Adoption: No Risk means No Gain. [online] Available at: < http://www.drillingcontractor.org/technology-adoption-no-risk-means-no-gain-13073 > [Accessed 28 October 2018], 2012

[10] IEA Geothermal, Innovative Drilling and Production Technology for Deep Geothermal Wells. [online] Available at: < http://iea-gia.org/wp-content/uploads/2016/05/2-04-LehrInnovative-Drilling-and-Production-Technology-for-Deep-Geothermal-Wells.pdf> [Accessed 27 December 2018], 2016

[11] IEA Geothermal, Summary of New Drilling Technologies. Germany: IEA Geothermal, 2017

[12] Ihsmarkit, Technology and Innovation Key to Cost Reduction and Capital Efficiency as Companies Strive to Meet Future Energy Demand. [online] Available at: < https://news.ihsmarkit.com/press-release/bp-technology-review/technology-andinnovation-key-cost-reduction-and-capital-efficien > [Accessed 13 January 2019], 2015

[13] Medal, A, How Technology is Saving Oil and Gas Industry. [online] Available at: < https://www.inc.com/andrew-medal/how-technology-is-saving-oil-gas-industry.html> [Accessed 29 December 2018], 2017 
[14] Metallurgist, Water Jet Rock Drilling. [online] Available at: < https://www. 911metallurgist.com/water-jet-rock-drilling/ > [Accessed 18 November 2018], 2018

[15] Milmo, S., Fracking with Propane Gel. [online] Available at: https://www.chemistryworld.com/news/fracking-with-propane-gel/3001695.article > [Accessed 25 September 2018], 2011

[16] Nahkle, C., New Technological Frontiers in the Oil and Gas industry. New York: Newsweek Vantage, 2018

[17] Nielsen, S. M, Microbial Enhanced Oil Recovery - Advanced Reservoir Simulation. PhD. Technical University of Denmark (DTU), 2010

[18] Nunoo, N. A., Open Innovation in Drilling. [online] Available at: < https://www.spe.org/en/print-article/?art=3250> [Accessed 02 February 2019], 2017

[19] OG21, Technologies to Improve Drilling Efficiency and Reduce Drilling Cost. Norway: OG21, 2014

[20] Oil and Gas Journal, Innovation from Smaller Service Firms. [online] Available at: <https://www.ogj.com/articles/ogfj/print/volume-11/issue-12/features/oilfield-servicestechnology-a-special-report/innovation-from-smaller-service-firms.html > [Accessed 29 October 2018], 2014

[21] Oil and Gas Product News, Turbine drilling solution proves successful in hard Montney shale formations. [online] Available at: < https:// www. oilandgasproductnews. com/article/20954/turbine-drilling-solution-proves-successful-in-hard-montney-shaleformations > [Accessed 20 February 2019], 2015

[22] Oil and Gas, Drilling Technologies [online] Available at: $<$ http://www.oilgasportal.com/drilling/technologies/> [Accessed 09 February 2019], 2017

[23] Oil Industry Training, Overview of Drilling Process. [video online] Available at: <https://www. youtube. com/watch?v=2QlH2fhWEAc > [Accessed 19 January 2019], 2017

[24] Presley, J., Best of 2017: Drilling, Cementing Technologies Recognized For Innovative Designs. [online] Available at: < https:// www.epmag.com/best-2017-drilling-cementingtechnologies-recognized-innovative-designs-1671506>[Accessed 20 December 2017], 2017

[25] Quora, What are the new innovations in oil well drilling technology? [online] Available at: $<$ https://www.quora.com/What-are-the-new-innovations-in-oil-well-drillingtechnology> [Accessed 20 February 2019], 2018

[26] Shell, Monodiameter Drilling. [online] Available at: < https:// www .shell. $\mathrm{com} /$ careers/experienced-professionals/technical-careers/wellsengineering/monodiameter-drilling.html > [Accessed 02 August 2018], 2018

[27] Shirkavand, F., Hareland, G., and Olson, W, The Design and Development of a Drilling Simulator for Planning and Optimizing Under-Balanced Drilling Operations. Journal of Canadian Petroleum Technology, 49(6), 2010, pp. 177-189.

[28] SPIE, High-power fiber lasers for geothermal, oil, and gas industries. [online] Available at: <http://spie.org/newsroom/5288-high-power-fiber-lasers-for-geothermal-oil-and-gasindustries?SSO=1> [Accessed 02 October 2018], 2014 
[29] Tablot, D, The End of Easy Oil. [online] Available at: < https:// www technologyreview com/s/420404/the-end-of-easy-oil/ > [Accessed 12 December 2018], 2010

[30] Tarver, E., Why the Price of Crude Oil Dropped in 2015? [online] Available at: < https://www.investopedia.com/articles/investing/102215/4-reasons-why-price-crude-oildropped.asp > [Accessed 15 November 2018], 2018

[31] Wang, B.,Microwave oil recovery could unlock trillions of barrels of oil and drinkable water from Oil shale and oil sands. [online] Available at: < https://www.nextbigfuture.com/2016/12/microwave-oil-recovery-could-unlock.html > [Accessed 14 December 2018], 2016

[32] Wikipedia,New Drilling Technologies. [online] Available at: < https://en.wikipedia.org/wiki/New_drilling_technologies> [Accessed 28 September 2018], 2018

[33] Zahid, A., Smart Waterflooding in Carbonate Reservoirs. PhD. Technical University of Denmark (DTU), 2012 